\title{
HERITAGE CONSERVATION: AUTHENTICITY AND VULNERABILITY OF LIVING HERITAGE SITES IN MELAKA STATE
}

\section{Rahimah Abdul Aziz}

School for Social, Development and Environmental Studies, Faculty of Social Sciences and Humanities, Universiti Kebangsaan Malaysia, MALAYSIA E-mail: ikra@ukm.edu.my

Published online: 29 December 2017

To cite this article: Rahimah Abdul Aziz. 2017. Heritage conservation: Authenticity and vulnerability of living heritage sites in Melaka state. Kajian Malaysia 35(Supp.1): 39-58. https://doi.org/10.21315/ km2017.35.Supp.1.3

To link to this article: https://doi.org/10.21315/km2017.35.Supp.1.3

\section{ABSTRACT}

Melaka Historical City, together with George Town, Penang, were conferred the United Nations Educational, Scientific and Cultural Organization (UNESCO) World Heritage Site (WHS) in 2008. One of the requirements in order to remain in the listing is a high degree of local community participation in its continued conservation. This is in order that the local communities who are regarded as stakeholders and custodians of the sites would actively participate in their protection. Similarly, living heritage sites in Melaka seek to recreate historical settings to simulate past time periods, thus providing visitors a glimpse of what it would be like to live in the past. Such sites call for the participation and involvements of the ethnic-specific group to shape and preserve its cultural heritage and identity. Living heritage sites can also be regarded as a way for the community to seek relevance especially in a multi-cultural society. However, authenticity is among the major concerns of the living heritage sites as well as other factors that they encountered in the face of modernisation and development that subsequently contribute to their vulnerabilities. The focus of this article is the living heritage sites in Melaka. The discussion is based on the study of the three living heritage sites in Melaka. The living heritage sites are Kampung Morten, Kampung Chetti and Kampung Portugis. In-depth semi-structured interviews were conducted with various key individuals of the three communities as well as focus group discussions with members of the community. The study shows that although there are concerns that need to be addressed the informants believe that through the living heritage 
sites the community members are able to express their cultural identity, pride and knowledge to their younger members as well as share them with the society in general.

Keywords: authenticity, vulnerabilities, heritage conservation, living heritage sites, cultural heritage

\section{INTRODUCTION}

UNESCO has a list of heritage sites that are conserved for present and future generations. Over recent years Malaysia had successfully gained United Nations Educational, Scientific and Cultural Organization (UNESCO)'s listings for some of its natural and cultural heritage. Under the World Heritage Site (WHS) listings there are Kinabalu National Park, Sabah (2000), Gunung Mulu National Park, Sarawak (2000), Melaka and George Town, Penang (2008) and Lenggong Valley in Ulu Perak (2012) while the Langkawi group of islands was designated the status of a geopark, the first in Southeast Asia (2004). One of the requirements in order to remain in the listing is a high degree of local community awareness of the WHS and participation in its continued conservation efforts. This is in order that in the process of complying with UNESCO's requirements of continued listing, the local communities who are regarded as active stakeholders would develop a sense of ownership and custodianship of the sites and thereby would participate in their protection.

Similarly, the existence of living heritage sites in Melaka involves the participation and involvement of the ethnic-specific group in the quest to preserve its cultural heritage and identity. An ethnic-specific group generally lives in and/ or manages the living heritage museum. The living heritage sites can generally be regarded as an attempt to represent or sustain the community's heritage and directly or indirectly help the said community and also its village to sustain. Such sites can also be regarded as a representation or a "living past" that exists in the present and as a way for the community to seek relevance especially in a multicultural society. As such for the people of various origins having their own living heritage site would help them preserve their collective memories of the past as well as help them retain their uniqueness as a community - their identity - based on the past events and in the face of present experiences. Also, such sites would contribute towards "...building and reinforcing their specific sense of history and identity..." (UNESCO, 2010).

Melaka is a multiethnic and multicultural state as a result of its history of interrelations with various countries of the world that span more than 500 years. The various colonial powers that had successively ruled Melaka between 1511 
until 1957 had left significant deep-rooted impacts in Melaka's culturalscape. The intermingling and interrelationships of the various races and ethnic groups during that period had produced its multiethnic and unique multicultural heritage. These are hybrid communities and cultures - a unique blend of cultures of the foreign traders and the locals - such as the Peranakans (Baba-Nyonya) or Straits born Chinese who speak a mix of Malay and Hokkien, Chetti (Chitti) or Indian Peranakans and Portuguese Eurasians or Kristang (Cristao). The influences of Asia and Europe have endowed Melaka with a multicultural tangible and intangible heritage. Due to its unique multicultural living heritage originating from the trade routes and other outstanding universal values (OUV) that it possesses, on 7th July 2008 Melaka City was listed as a UNESCO WHS together with George Town of Penang. Together they form the Historic Cities of the Straits Settlements. Being recognised as a WHS Melaka City is required to preserve and maintain its unique historical and cultural heritage be they tangible or intangible. It is not permitted to demolish or significantly modify the appearance of its historic buildings. Also, in compliance with the requirements, Melaka need to increase awareness regarding the WHS especially among its population, build a sense of custodianship as well as secure support by promoting its significance.

Over the last two decades and especially since Melaka and George Town were listed as WHSs by UNESCO in 2008, Melaka has witnessed a growth in the number of museums established in the state. International Council of Museums (ICOM) (2002) defines museum as "non-profit making, permanent institution in the service of society and of its development, and open to the public, which acquires, conserves, researches, communicates and exhibits, for purposes of study, education and enjoyment, material evidence of people and their environment...". Generally, museums are understood as formal places for heritage preservation and displays that connect a society to its history. They provide authoritative historical and cultural knowledge thus enabling the public to understand the past that has been made meaningful in the present (Corsane, 2005; Huber, 2011).

There are at least 29 museums and nine galleries located throughout Melaka (Perbadanan Muzium Melaka [PERZIM]). They can be generally categorised based on their objectives and functions (state museums, private sector museums and private museums). Some of the museums occupy the old colonial buildings located in the core zone of the heritage site. However, except for the Baba-Nyonya Heritage Museum, Chetti Museum and the Indigenous People Museum, none of the other museums is dedicated to any particular ethnic group, least of all the many ethnic minorities in Melaka. Majority of the museums are also not the typical public museums. Rather they are thematic or specialised such as the Maritime Museum, Melaka Stamps Museum, Malaysia Youths Museum and the Museum on Agriculture. Melaka also possesses a History and Ethnography Museum, which was established in 1954. However, as said by Handler and Gable 
(1997), such museums often ignore the dialogical aspects of people's social practices that take place inside and beyond their walls. Also, the exhibits in the museum can be said to be authority-defined in that the authority controls the telling of stories, what should be exhibited and the representations of the ethnic groups. This has resulted in some ethnic minority groups feeling that they are not represented or that they are being underrepresented. Being listed as a WHS, it is very important that the culture of the various ethnic groups that make up Melaka's cultural heritage mosaic be conserved as required.

As well the conventionally understood museums and galleries, Melaka also has at least three known living heritage sites. The existence of these living heritage sites is partly due to the local (site) community taking it upon themselves to protect their traditions and heritage. The everyday lives of the villagers are made more meaningful when the link is made with heritage matters. In fact it is without doubt that besides the authorities, the local (site) community participation and involvement is a crucial factor to safeguard their heritage and to promote conservation. This is because they are the local custodians of the heritage sites. Besides helping to preserve the cultural heritage of the different minority ethnic groups, these sites are perceived to be able to attract the tourists that had come to visit the state. In Melaka there are three villages that had been the enclave of three distinct ethnic groups - Malay, Chitties and Portuguese Eurasians. The villagers in the sites carry out their daily lives, practicing their cultural traditions that had been passed on them from generation to generation. In these villages and through their various activities each village is able to highlight their cultural uniqueness.

This article focuses on the living heritage sites in the historical state of Melaka. It will discuss the issue of authenticity and other concerns that those sites encountered in the face of social change and development. The discussion is based on the study conducted from May 2013 to December 2014 of three living heritage sites in Melaka, which are Kampung Morten, Kampung Chetti and Kampung Portugis (Portuguese Settlement) (Rahimah et al., 2015). For the study a series of in-depth interviews were conducted with various key individuals and community leaders of the respective living heritage sites. A semi-structured interview schedule was used to generate discussion and elicit information. For convenience all the informants were interviewed on-site. This is to allow the researchers the opportunity to follow up on some of the informants' responses related to their respective community. Focus group discussions were also held with the ordinary members of the respective community. The objective is to link the broader historical and cultural developments to experiences and perceptions at the group as well as individual levels as they understand it (Rahimah et al., 2015). 


\section{HERITAGE CONSERVATION AND LIVING HERITAGE SITES}

Generally, heritage is understood as the past that had been preserved or conserved not only for the benefit of the present generation but will also be inherited by the future generations. In other words, heritage can be regarded as anything that someone wishes to conserve or to collect and to pass on to future generations (Howard, 2003: 7). However, although anything can become heritage, not everything is heritage unless recognised as such (Howard, 2003: 7-8). Conservation, on the other hand, can be defined as protection from any agent - environmental or human - that threaten to destroy heritage. Conservation efforts aim to protect heritage from human practices of the present that are considered to be harmful, and transmit it to the future generations while ensuring its accessibility to both the present and future generations. Thus, conservation ultimately is also about promoting good land uses, for the benefit of people, future generations and the land itself (Freyfogle, 2006: 144). It helps a community to protect its economically valuable physical assets and to preserve its history and environment besides protecting the community's sense of identity and continuity.

A living heritage site, on the other hand, is a site which attempts to recreate historical settings to simulate past time periods, providing visitors with an experiential interpretation of history. It is a site that recreates the conditions of a culture, natural environment or historical period. Conceptually, it is a site with fixed boundaries and a local community living permanently within it. The livein community is thus differentiated from the surrounding communities as it has special association with the site and its functional continuity. To the community the site is their home as it gives them a sense of identity, provides them with a sense of security as well as meaning to their lives (International Centre for the Study of the Preservation and Restoration of Cultural Property [ICCROM], 2015; Poliaus, 2014).

Living heritage is characterised by the ongoing use of heritage by its associated community for the purpose for which it was originally created... (it) is strongly linked to a community and is therefore subject to a continuous process of evolution as change is embraced as part of the living nature of the heritage place.

(ICCROM, 2015: 4)

Conceptually, living heritage site is linked to the concept of continuity particularly continuity of heritage original functions. In such a site the community maintains continuity from the past by maintaining their cultural heritage (both tangible and intangible) via traditional or established means. However, the emphasis is more on the intangible connection of the community with heritage 
rather than the tangible (Wijesuriya, 2005 in Poliaus, 2014). Theoretically, this community is thought to receive minimal impact or not at all of modernisation, urbanisation and globalisation processes. It is a site whose community claims a special strong social, spiritual or other cultural association with it (ICOMOS Australia 1999, Article 12: 5). Conservation of these sites means that they have the ability to provide present-day and future visitors with authentic experiences. Nevertheless, despite attempts by the heritage authorities to protect a community's "traditional" association against contemporary "influences", the latter often prevail, with a serious impact on the former.

\section{STUDY AREA: LIVING HERITAGE SITES IN MELAKA}

There are three traditional villages that had been gazetted by the Melaka State Government under the Conservation and Preservation of Cultural Heritage Enactment 1988 (Amended 2008). In Section 4 of the Enactment it is stated that the State Authority may declare any cultural heritage to be subject to preservation and conservation on the recommendations of the Local Authority. It may also designate the area within which such heritage is located as conservation area. While Section 5 of the Enactment further stated that the jurisdiction for the control, enforcement, development, preservation and conservation of every cultural heritage and conservation area shall be vested in the Local Authority (Nizamuddin, n.d.). The villages in question are Kampung Morten, Kampung Chetti, and Kampung Portugis (Portuguese Settlement).

Being distinctive and also by definition, these traditional villages can be referred as living heritage sites. These traditional villages are living heritage sites by virtue of the fact that its inhabitants still practice a life style that has remained relatively unchanged since its founding besides exhibiting the architectural uniqueness of their houses as well as their cultural practices.

\section{Kampung Morten}

Kampung Morten (Figure 1) is a traditional Malay riverine village located just outside the designated UNESCO's WHS. It has been declared a traditional Malay heritage village by the Melaka State Government in 1988. This recognition was gazetted under the Melaka state's Preservation and Conservation Enactment. It is probably the only surviving traditional Malay village with its old-world charm in the city of Melaka. This is because since its founding in 1922 until now it has succeeded in retaining its Malay identity despite having to face various modernisation and development processes. This can be seen through its home architecture, interior decorations, landscape and cultural practices. 


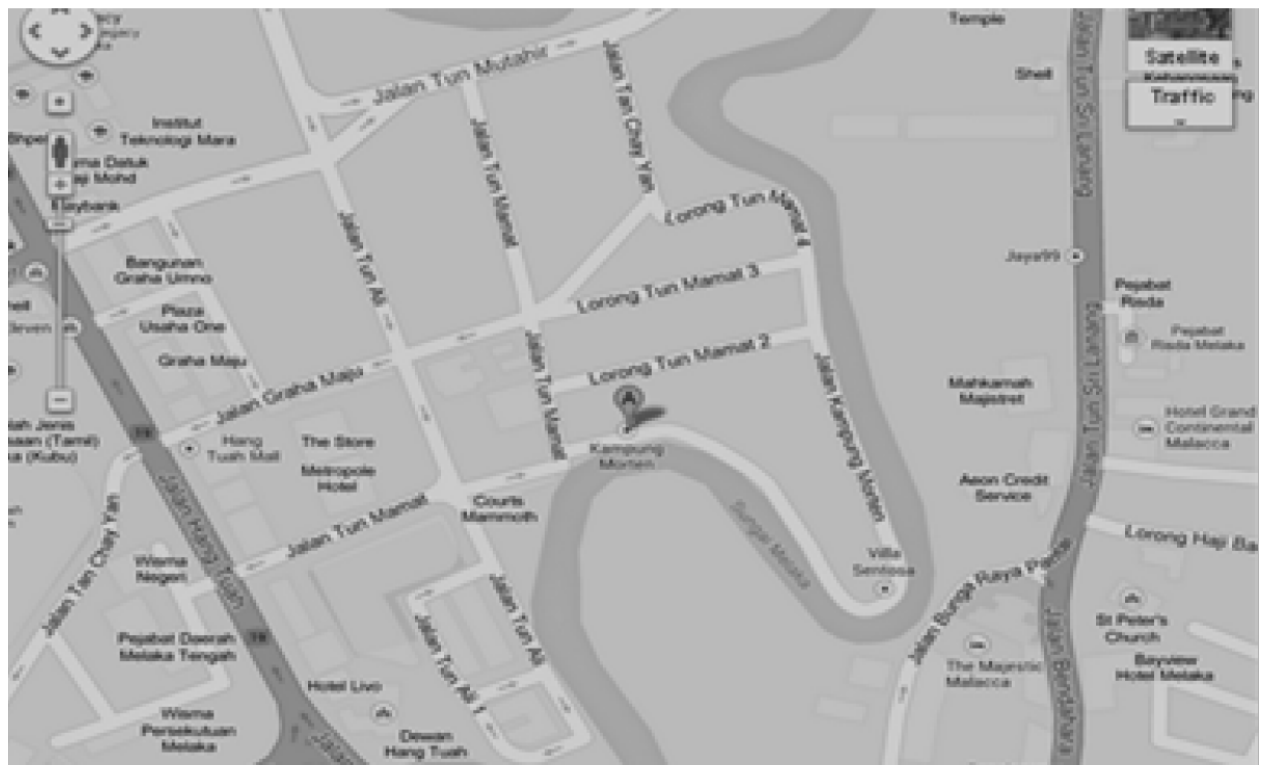

Figure 1: Map showing location of Kampung Morten.

Source: Google Maps (2014).

Kampung Morten was given its name in memory of J. F. Morten, the Land Commissioner who had played a significant role in helping the then residents to collect and secure enough money to purchase an approximately five hectares (12 acres) piece of land that had been identified as their future settlement. Kampung Morten, was also once known as Kampung Baru (New Village) because initially its inhabitants comprised settlers from four different villages (Kampung Jawa, Kampung Jawa Pantai, Kampung Johol and Kampung Solok Darat Serambai). However, after the land was gazetted, the name Kampung Baru was dropped and the name Kampung Morten is retained to this day (Rahimah et al., 2015; Sr Brit Anak Kayan, 2015; starproperty.my, 2013).

Within the Kampung is a private museum which depends on contributions from visitors for its upkeep. The museum is in a traditional house, named Villa Sentosa, built in 1921 and owned by the village first headman Othman Muhammad Noh. The living museum provides further insight on how nine generations of the owner's descendants lived in the house and kept its traditions. Among the artefacts in this private museum are antique furniture, ceramics, and ancient weapons. There is also a special wedding room complete with a dais which had been used for Othman's descendants (Rahimah et al., 2015). 


\section{Kampung Chetti}

Kampung Chetti (Chitti) is a two hectares (five acres) village located off the main road at Jalan Gajah Berang and outside of the Melaka WHS (Figure 2). At the time of the study there are around 30 Chetti families living in the village. The community members do not individually own the site. Most families in the village are extended families with at least three generations in each household. However, due to lack of space many family members had moved out to a different house or even different location. Nevertheless, they would still return home during important festivals and religious celebrations for reunions with family members and to reaffirm their Chetti identity. Within the site, the Chettis or also referred to as Peranakan Indian practice their culture and maintain their identity. In 2002 Kampung Chetti was gazetted as a heritage village by the Melaka State Government (Rahimah et al., 2015; Pillai, 2015).

The Chettis are descendents of the once thriving 14th century Tamil merchants who had settled in Melaka. The Indian-Tamil males who married local women had made Melaka their home. Consequently, a sub-community or a hybrid ethnic community flourished over time as a result of intermarriage and adaptation process to the local way of life and a mixture of two different life styles, that of the Indian-Tamil and the local. This hybrid community is named Chetti (or Chitti) which in Tamil means traders who originated from Kalingga in India. The Melaka Chettis speak Creole language or bazaar Malay mixed with Tamil (Rahimah et al., 2015; Pillai, 2015).

Kampung Chetti is both a residential and religious space. It continues to serve as a spiritual and cultural base for the community. There are all together ten temples and shrines owned and managed by the Temple Trust that also managed the community land. Three of the temples built in the 19th century are located within the village including the 190 years old Sri Maha Mariamman Temple where many religious ceremonies are held including Deepavali, Bhogi, Ponggal, Amman Thirunal and the annual devotion to Goddess Mariamman. These religious ceremonies and events attract many devotees and visitors. Although many aspects of the Chetti culture portray indigenous influences - language, clothes, cuisine the core of the culture remain the orthodox Hindu beliefs. In fact religion acts as an important identity indicator for the Chettis.

Within the Kampung Chetti living heritage site there is also a Chetti Museum. Established in 2003, the museum represents efforts by members of the community to collect, document and preserve their unique heritage. The museum holds the community's history. It houses a collection of artefacts used by the community in their daily lives, such as tools, clothes and accessories, as well as during the special occasions, such as weddings and childbirth. The displays are divided into sections and each section takes the visitors through each phase 
of the life cycle. Not only are the customs and traditions for each stage of the life cycle documented and displayed, but also the food served during the various ceremonies, clothes worn and tools and utensils used. The artefacts that are sourced and collected from the community members are either donated or on loan to the museum. Although the museum receives state sponsorship and Melaka Museums Corporation's (Perbadanan Muzium Melaka, PERZIM) assistance, the museum is still cared for and managed by the Chettis. The entrance fee to the museum is RM2, which is less than USD1, but the collection is handed to PERZIM (Rahimah et al., 2015).

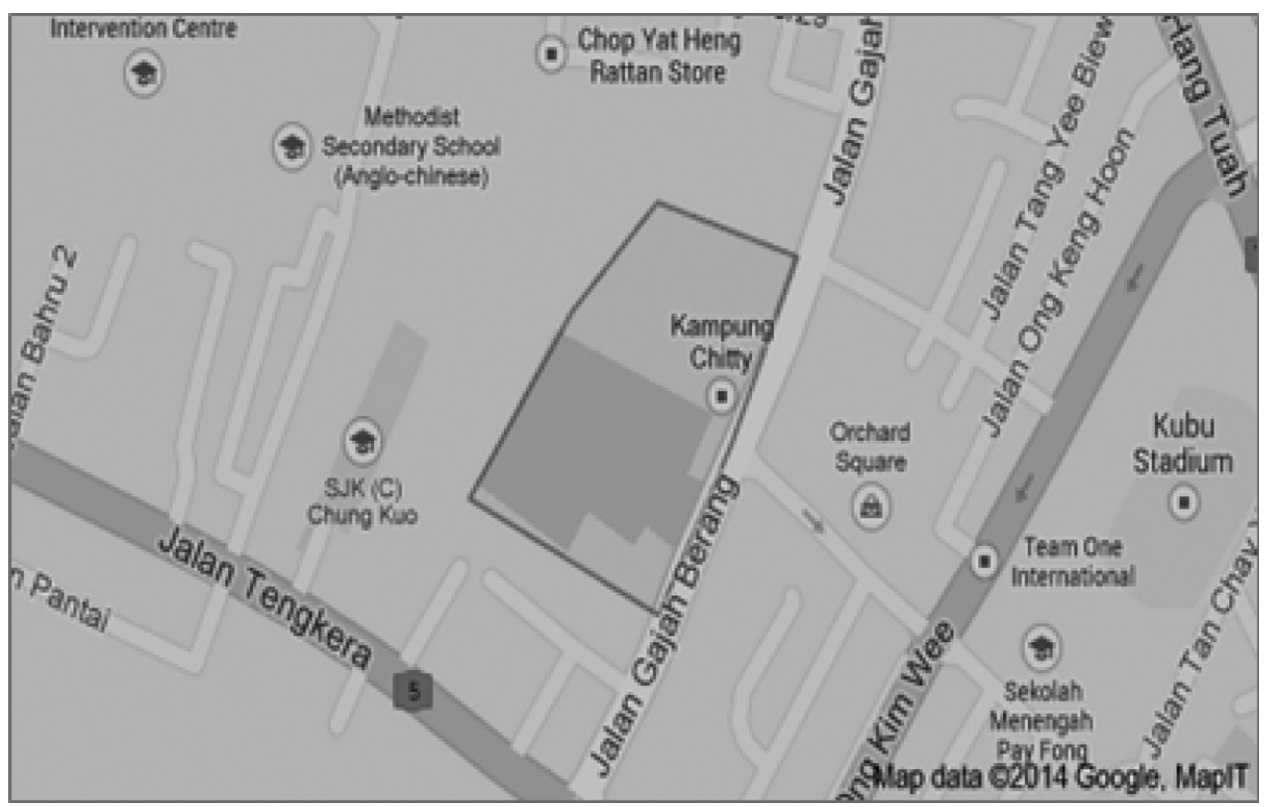

Figure 2: Map showing location of Kampung Chetti. Source: Google Maps (2014).

\section{Kampung Portugis}

Intermarriage between the Portuguese and the locals had produced a hybrid ethnic community or sub-community called Portuguese Eurasians or Kristang. Initially, the group was dispersed but in 1934 the community of fishermen was given an 11.5 hectare site by the sea to build their settlement. The Kampung Portugis or Portuguese Settlement as it is known today is located at Ujong Pasir Melaka, about two kilometres south of the Melaka city center (Figure 3). The settlement was originally called St. John's village but was renamed as Kampung Portugis (Portuguese Settlement) by the British. In 1990, this settlement of 
about 110 dwellings was gazetted as a heritage village under the Melaka State Preservation and Conservation Enactment (Rahimah et al., 2015).

This community speaks Portuguese Creole called Kristang and practice a hybrid culture, which is a mixture of different aspects of other cultures (Malay, Portuguese, Dutch, English, Indian, etc.). They, however, strongly embrace their Catholic religious beliefs. Festa San Pedro is a feast of great significance to the community. This event attracts other Portuguese-Eurasians from across Malaysia and from abroad as well as other visitors. The event sees the combination of reverence and revelry. The religious rituals are followed by carnival like celebrations with Portuguese-Eurasians cultural shows and cuisines. Other religious events and celebrations include the San Juang Fiesta (light festival) and Christmas.

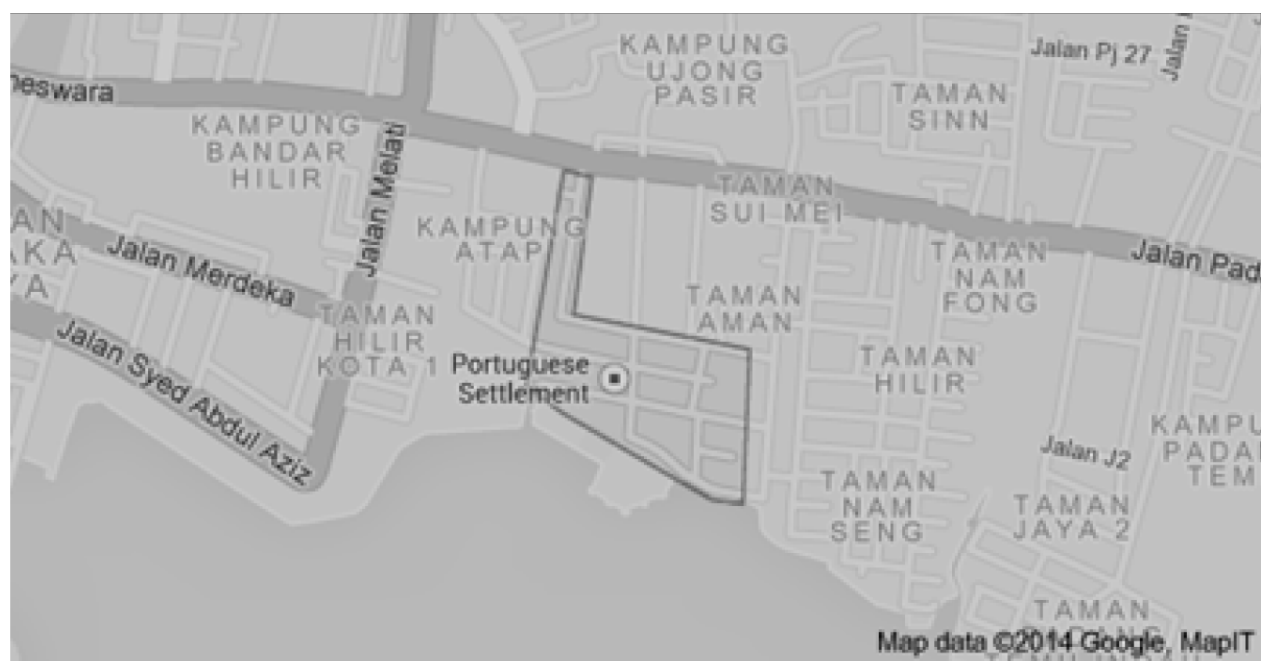

Figure 3: Map showing location of Kampung Portugis.

Source: Google Maps (2014).

Within the Portuguese Settlement is a Portuguese Museum that was set up in 2006. The small single room museum houses a modest collection of items, which traces the history of the Portuguese community in Malaysia. It offers some explanations, descriptions and pictures of the settlement and some artefacts. The artefacts are divided into two sections: one section displays artefacts that are directly linked to Portugal. The national flag of Portugal is strategically hung to show the community's link to the country. The other section displays artefacts donated by or on loan from the community members. Visitors are charged an entrance fee of RM1/= or less than USD1 to view the exhibits. According to one of the informants, PERZIM had offered to fund and help manage the museum but the community through its committee had declined the offer. The community wants 
the museum to be managed and run by its own community members. However, the museum is not well publicised and, as a result, is seldom open to the public (Rahimah et al., 2015).

\section{AUTHENTICITY AND VULNERABILITIES}

Generally, the fieldwork discussions found that the informants of the three heritage villages believe that the existence of the living heritage sites enable them to advance their cultural pride and identity to their community members in particular and the society in general. Through shared knowledge they are able to create cultural awareness among the general public about their respective cultural heritage. Visitors to these villages cum living heritage sites are able to learn, for example, of the clothes worn by the respective ethnic groups in the past, the kind of food they consumed, and the music that they listened to.

However, Melaka living heritage sites are faced with concerns related to authenticity. Also they have to deal with issues that are perceived as contributing to the vulnerability of their existence or survival such as the modernisation and development processes taking place in the Melaka state; participation and involvement of members of the respective community; and the rise of the tourism industry.

\section{Authenticity Concerns}

One of the major concerns at the living heritage sites and in the process of heritage conservation is the idea of authenticity, which has always been a challenging concept. This is due to its original implication as well as differing perceptions and understanding of the concept between various societies. "Authenticity" is essentially a western concept with its objectives the preservation of physical heritage of the past from loss and depletion in the present based on the idea that authenticity of sites and objects are non-renewable. The importance of the concept of authenticity within the context of heritage conservation was formally established at the international level with the adoption of the Venice Charter (ICOMOS, 1964) and especially the Convention Concerning the Protection of the World Cultural and Natural Heritage (henceforth cited as the World Heritage Convention) (UNESCO, 1972). In the context of the World Heritage Convention, authenticity may be seen as "... effort to ensure that those values are credibly or genuinely expressed by the attributes that carry those values..." while integrity as "...effort to refer to the completeness of the cultural heritage system which holds or contains those values ..." respectively (Stovel, 2004: 131). It was clear that the word "authenticity" is often understood in different ways and in some cases 
even in conflicting ways, and varies with every country and society. Consequently, these different opinions about authenticity also resulted in different values being accorded to the historic subject, and thus also on the conservation of the subject. Some countries prefer to preserve the original, genuine material of a historic place or object, even when this is incomplete. Others prefer to have a complete image of the original shape (even with the use of new material). And, for another group it is the location that is important (Byrne, 2014; Kwanda, 2010).

Temporal change is not the only influence on authenticity. The World Heritage program also accepts that different cultures interpret the concept in different ways (Labadi, 2007), and it has convened several conferences to discuss such ambiguities. The first and most significant of these, the Nara Conference on Authenticity in 1994, gave rise to The Nara Document on Authenticity, which outlines how the term "authenticity" should be interpreted (World Heritage Centre [WHC], 2008: Annex 4: 93-97). As stated in this document, "Cultural heritage diversity exists in time and space, and demands respect for other cultures and all aspects of their belief systems" (Annex 4: 93-107; Annex 6: 113-119). Authenticity of cultural heritage must, therefore, be judged in its own cultural context.

The Operational Guidelines has defined authenticity in fairly broad terms but suggest that cultural values must be "truthfully and credibly expressed through a variety of attributes" in order to maintain authenticity (World Heritage Centre [WHC], 2008: 82). These attributes include form and design, materials and substance, and location and setting. The less tangible notions of function, tradition, and spirit are also considered important (Stovel, 1998). As described in the Management Guidelines, "... Generally speaking, authenticity is ascribed to a heritage resource that is materially original or genuine as it was constructed and as it has aged and weathered in time.

Basically, authenticity refers to perfect simulations between a living history activity and the piece of the past it is meant to recreate (Handler and Saxton, 1988). However, it also includes the use of original objects. In fact generally something is considered authentic if it is made, produced or enacted by the local people according to customs and traditions and has connotations of traditional origin. Thus, it implies that the context and concept that are exhibited and communicated in the present time require accuracy and truth of the past. This is especially complex with regard to intangible cultural heritage. Several specific problems exist. First, authenticity has different meanings in different cultural contexts, as well as to diverse stakeholders, making it problematic to reconcile the demand for common preservation standards across cultures. Second, many sites are multilayered, for they have evolved over long time periods, and different groups of people have shaped them. In these situations power relationships enter into decisions about whose heritage or which time period frame preservation and 
interpretation. Third, especially in historic cities and culturalscapes, tensions exist between demands for preservation approaches aimed at a high degree of authenticity and integrity and the needs of the people who inhabit these sites. Finally, other stakeholders have their own goals for sites, which may or may not be compatible with preservationists' aims. Tourists, in particular, come to the sites with specific expectations of the "authentic" experience that they would like to have, which often do not tally well with the recorded history of the site. In addition, many visitors to sites expect a certain standard of comfort, setting up yet another compromise between maintaining the authenticity of the site and providing the facilities that tourists expect.

In the Melaka living heritage sites, some events have been "commercialised" to attract tourists and for economic gain to the point that their authenticity is compromised. In a bid to attract tourists and visitors cultural performance are packaged to generally include songs, dances and in some instances wedding ceremonies (Rahimah et al., 2015). These performances are named as authentic inheritance that had been passed on for generations, when they are actually adaptations of the original culture that was brought into the country, plus local creations. For example, the Christmas celebration at the Portuguese settlement. Certain traditions are kept that create meaning and experiences for the participants, especially visitors and tourists, that enable them to go back in time to the very heart of the Kristang culture. However, it cannot be denied that some adaptations have been made to suit present need and demands.

Thus, questions often arise regarding the originality or authenticity of exhibits displayed, festivals celebrated and ceremonies re-enacted. Are they really authentic or just representations of the past? Furthermore, emphasis on preservation of the fabrics of the sites in most cases is not possible as it is difficult to source original materials. Also, it can be very expensive to repair and restore a building or a site to its original state. Thus, a partial replacement of existing material or a change of fabric or even total physical renewal or replacement of the entire structure is essential for the survival and continuation of the living heritage sites. This has resulted in alternative materials being used and thus compromising authenticity or originality (as understood by some) of the historic part.

\section{Vulnerabilities}

Besides concerns regarding the authenticity of the heritage that are being conserved and handed down the generation, another issue that was raised by the informants and participants is that of being vulnerable to the events that are taking place around them, but of which they have no control. Vulnerability is generally conceptualised as the risk of being exposed or susceptible to the possibility of harm, either physically or emotionally due to the inability of a community or 
individual to withstand adverse impacts due in part to characteristics inherent in social interactions, institutions and systems of the society. It is a human condition or process resulting from physical, social, economic and environmental factors which determine the likelihood and scale of damage from the impact of the given hazard (United Nations Development Programme [UNDP], 2004: 11). Cutter, Boruff and Shirley (2003) sees social vulnerability as partially the product of social inequalities - that is those social factors that influence or shape the susceptibility of certain groups to harm and that also govern their ability to respond (also see Singh, Mohammad Reza and Singh, 2014). However, being a dynamic concept the conditions that give rise to vulnerabilities can be altered, reinforced or diminished.

In the case of the three living heritage sites in Melaka, among others the communities are feeling vulnerable to the impact of the development processes that are taking place around them. They are also apprehensive of the impact of the rise of tourism industry on their authentic culture and the decreasing involvement of community members, especially from among the younger generation, in safeguarding their heritage.

\section{Hazards of modernisation and development processes}

Generally, modernisation and development processes present a challenge to heritage conservation. Many forms of cultural heritage are in danger of disappearing threatened by these processes. The rapid-paced modernisation and development processes taking place in Melaka state, particularly in the areas outside of the Melaka WHS have somewhat impacted on the integrity of these living heritage sites. Although Kampung Morten, Kampung Chetti and Kampung Portugis are all located outside of WHS, they had all been gazetted as heritage sites by the Melaka State Government and, as such, should be protected from the encroaching development. These living heritage sites had directly or indirectly contributed to the recognition of Melaka as WHS by UNESCO. They also contribute towards attracting tourists and visitors to the state. However, the surrounding high-rise buildings towering and overlooking Kampung Morten, the land reclamation activity taking place barely 200 meters from the seafront of Kampung Portugis, and a 22-storey building, as well as a hotel being built near Kampung Chetti plus a proposed road that would cut across the village have resulted in the sites slowly losing their luster and attraction.

Development processes in the surrounding areas of the villages have impacted their status and integrity as traditional heritage villages. Despite having been gazetted by the Melaka state as heritage villages and in the case of Kampung Chetti and Kampung Portugis having a 500-year link to the Melaka Sultanate, the development activities have resulted in the villagers feeling threatened and vulnerable. Environmental pollution and poor planning contribute towards the 
destruction of their aesthetics. These incompatible development activities have inadvertently threatened the survival and sustainability of the three settlements and their socio-cultural heritage, which were among the very things that had attracted tourists and visitors to visit Melaka state in the first place.

Being located in the fast growing Melaka city also makes the villages attractive to developers. Although located outside of the WHS core zone, nonetheless being near to the zone plus the rapid expansion of the city has led to the areas becoming increasingly economically valuable. This has resulted in many profit-oriented quarters taking advantage of the situation for their vested interest. Besides that the villages are exposed to risk posed by other types of development projects not directly associated with conservation.

\section{Decreasing participation and involvement of members of the respective community}

The informants from Kampung Chetti and Kampung Portugis also stressed their concerns regarding their younger generation slowly losing their ethnic heritage and identity under the onslaught of modernisation and globalisation processes in favour of adopting more modern values. The informants worry that the communities would lose their ethnic identity and cultural values because of these external influences as traditional knowledge is dominated by the modern way of life. As such through the living heritage sites, they hope to help the community members discover the value of their culture, to enhance their pride in their culture and in the process to keep their ethnic identity. However, their attempt to play the role of guardian of shared memories and as transmitter of their cultural knowledge to the younger generation has met with varying degree of success (Rahimah et al., 2015).

\section{Impact of rise of tourism industry}

Often times tourism is touted as a means by which heritage can bring economic benefits to the related community. In fact, tourism industry has been a powerful force in creating social change, especially in places that have been declared heritage sites. However, tourism has also its downside. The social changes brought about by the tourism industry can be both positive and negative. The commodification of certain aspects of heritage or culture can pose a threat to their traditional form. In fact in these places the rise of tourism industry has led to dilemmas regarding the maintenance of heritage sites without compromising the economic interests of the local community.

One of the important factors that have affected the lives of the three living heritage sites and its communities is the growth of the tourism industry. Melaka has rigorously developed its tourism industry to become one of the major contributors 
to economic growth. Among its selling point is the diversity of culture as a result of its history. The rich culture and heritage of Melaka, consequences of its relations with the outside world for over more than 500 years and intermarriage between the local people and the foreign traders, have become a symbol of cultural diversity and heritage that have attracted tourists to Melaka. For instance the year 2012, saw a total of 13.7 million tourist arrivals to Melaka compared with 12.5 million tourists in 2011 (Asmaliana, 2013), while in 2015 tourists arrival to Melaka increased to 15.7 million (Bernama, 2016).

Inadvertently, the local communities are increasingly drawn into the industry as a means of gaining financial benefits. The increasing involvement of the local communities in the industry has raised apprehension, if not fear, among some members of how commodification of heritage could threaten the authenticity of their culture for the sake of the tourist dollars. Many fear that the authenticity of their heritage would be sacrificed for entertainment and profit because oftentimes changes are introduced into tangible heritage such as rituals, dances, and cuisines to attract the tourists and to cater to their demand. Such actions weaken their cultural meaning and significance. The way intangible heritage is presented, promoted or "packaged" influences its practice or performance. Festivals, dances, and harvests are often performed following or in accordance with culturally prescribed events, seasons, and astrological calendars. Practices, expressions and traditions must adhere to culturally prescribed norms and standards that have been passed down. Visitors, however, expect to witness and enjoy cultural manifestations "on demand" and that they are made accessible or digestible. As a result, one common practice of tourism operators is to "hire" dancers to welcome visitors on arrival or while dining, effectively appropriating these for tourist consumption. The promotion of intangible heritage for tourism almost invariably evokes notions of cultural authenticity. The danger posed by tourism is that locals end up pandering to visitors' expectations, which are formed and implanted onto their minds by travel guides that romanticise, oversimplify or provide cultural caricatures usually filled with inaccurate portrayal, stereotyping, and labelling of relevant aspects of indigenous culture. The result has been a presentation of "staged authenticity". This also leads to "situational adaptation" (Xie, 2004) whereby indigenous traditions, expressions and practices evolve not from the genuine adaptations of locals to their mutable ways of life but from the attempt to satisfy tourists' curiosity. Cultural standards and norms govern the presentation of rituals and performances (in details such as what or what not to wear, materials to be used, gestures to be performed) but since visitors are usually ignorant or oblivious of their significance, they readily accept whatever is presented, regarding them as "exotic" or traditional. The impact this situation tends to produce is that the owners of such heritage may easily abandon prescribed norms and standards for performances and practices, serving to dilute and reduce its essence. Such an outcome does not directly contradict the premise 
that heritage tourism generates cultural pride and sense of identity but it does pose a challenge to heritage transmission as custodians of heritage debate what is acceptable or not in passing on their practices, knowledge and skills.

The villagers of Kampung Morten had also recounted during the discussion of how their privacy had been intruded by insensitive tourists. Having assumed the village to be a tourist site and ignorant of the fact that the houses are actually private dwelling places of its inhabitants, there are instances when tourists would enter the houses without seeking permission looking at every corner of the dwelling place. Some tourists even regard the inhabitants as employees of the place. Such intrusion and insensitivities create a sense of uneasiness among the villagers.

\section{CONCLUSION}

In some ways living heritage sites can be said to act as keepers and defenders of the cultural heritage of a community or society. The sites can be interpreted as an effort by the ethnic-specific groups to preserve their heritage and cultural knowledge, as well as their sense of cultural identity that they hope to pass on and share with the successive generations. However, the success of such sites in building and reinforcing their identity require the participation of the group members to collect and exhibit the artifacts that have particular meaning for the community from which they came and which are deemed overlooked or underrepresented in the public museums (United Nations Educational, Scientific and Cultural Organization [UNESCO], 2010). It also requires the active involvement of the relevant stakeholders especially the local custodians if they are to ensure the continuance of their legacies.

Museums, living heritage villages, archaeological sites - these are all dependent on an interaction between the site and the visitors. Interpretation of the layers of heritage, and clarity about what is authentic and what is not guides the visitor's experience and engagement with history. Settlements, culturalscapes, and museum sites must engage the cultural and natural heritage of the site to maintain authenticity about the past, present and future.

\section{ACKNOWLEDGEMENTS}

This article is part of the findings of a bigger study titled "Penglibatan Pihak Berkepentingan dalam Governans Pemuliharaan Warisan: Bandaraya Melaka Bersejarah" (trans. Stakeholders' Participation in the Governance of Heritage Conservation: Historical City of Melaka). The study was conducted from May 2013 to December 2014 by Universiti Kebangsaan Malaysia Governance for 
Heritage Conservation research team. The author would like to acknowledge the financial support of Universiti Kebangsaan Malaysia for this research project under code grants DPP-2013-074, DPP-2014-087 and DPP-2015-082. The author would also like to thank the research group members Ong Puay Liu, Sarah Aziz, Halimaton Saadiah Hashim, Sharina Abdul Halim, Geraldine Chan Kim Ling and Ruslin Amir for their unwavering support, team work and dedication in bringing the research to its successful conclusion.

\section{REFERENCES}

Andaya, B. W. and L. Y. Andaya. 1991. A history of Malaysia. MacMillan: London.

Asmaliana. 2013. Melaka in a glance. 27 March. http://asmaliana.com/blog/2013/03/27/ melaka-in-a-glance/comment-page-1/ (accessed 20 November 2017).

Bernama. 2016. 15.7 million visitors to Melaka in 2015. 6 January. http:/tourism-melaka. blogspot.my/2016/01/157-million-visitors-to-melaka-in-2015.html (accessed 20 November 2017).

Byrne, D. 2014. Counter heritage: Critical perspectives on heritage conservation in Asia. New York: Routledge.

Corsane, G., ed. 2005. Heritage, museums and galleries: An introductory reader. Routledge: New York. https://doi.org/10.4324/9780203326350.

Cutter, S. L., B. J. Boruff and W. L. Shirley. 2003. Social vulnerability to environmental hazards. Social Science Quarterly 84: 242-261. https://doi.org/10.1111/15406237.8402002 .

Freyfogle, E. T. 2006. Why conservation is failing and how it can regain ground. New Haven and London: Yale University Press. https://doi.org/10.12987/ yale/9780300110401.001.0001.

Galla, A. 1993. Heritage curricula and cultural diversity. Canberra: Australian Government Publishing Service.

Graham, B. and P. Howard. 2008. The Ashgate research companion to heritage and identity. Ashgate: England.

Handler, R. and E. Gable. 1997. The new history in an old museum: Creating the past at Colonial Williamsburg. USA: Duke University Press. https://doi.org/10.1525/ can.1988.3.3.02a00020.

Handler, R. and W. Saxton. 1988. Dyssimulation: Reflexivity, narrative and the quest for authenticity in "living history". Cultural Anthropology 3(3): 242-260. doi.10.1525/can.1988.3.3.02a00020.

Howard, P. 2003. Heritage: Management, interpretation, identity. London: Continuum.

Huber, M. W., ed. 2011. Museums and memory. Newfound Press: Tennessee.

International Centre for the Study of the Preservation and Restoration of Cultural Property (ICCROM). 2015. People-centerd approaches to the conservation of cultural heritage: Living heritage. Guidance Note. Rome: ICCROM. 
International Council on Monuments and Sites (ICOMOS). 1964. International Charter for the Conservation and Restoration of Monuments and Sites (The Venice Charter 1964). Second International Congress of Architects and Technicians of Historic Monuments, Venice. http://www.icomos.org/charters/venice_e.pdf (accessed 23 June 2017).

ICOMOS Australia. 1999. Burra Charter (fourth version): The Australia ICOMOS charter for the conservation of places of cultural significance. http://www.icomos.org/ australia/burra/html (accessed 23 June 2017).

ICOM Asia Pacific. 2002. Shanghai charter. http://archives.icom.museum/shanghai charter.html (accessed 23 June 2017).

Jones, S. 1996. Discourses of identity in the interpretation of the past. In Culture, identity and archeology: The construction of European communities, eds. P. GravesBrown, S. Jones and C. Gamble. New York: Routledge.

Kwanda, T. 2010. Tradition of conservation: Redefining authenticity in Javanese architectural conservation. In Heritage 2010 - Portugal: International Conference on Heritage and Sustainable Development, Evora, Portugal. 22-26 June.

Labadi, S., ed. 2007. World heritage: Challenges for the millennium. Paris: UNESCO.

Miura, K. 2008. The need for anthropological approaches to conservation and management of living heritage sites: A case study of Angkor, Cambodia. In Interpreting Southeast Asia's past: Monuments, image and texts, eds. E. A. Q. Bacus, I. C. Clover and P. D. Sharrock. Singapore: NUS Press.

Nizamuddin Alias. n.d. Melaka as a World Heritage Site: A study from the legal point of view (Melaka sebagai Tapak Warisan Dunia: Kajian dari pandangan perundangan). Jurnal Perspektif. 3(1): 60-77. http://www.myjurnal.my/filebank/published_ article/30508/5.PDF (accessed 23 June 2017).

Nordin Hussin. 2007. Trade and society in the Straits of Melaka: Dutch Melaka and English Penang, 1780-1830. Singapore: National University of Singapore (NUS) Press.

Pillai, P. 2015. Yearning to belong. Malaysia's Indian Muslims, Chitties, Portuguese Eurasians, Peranakan Chinese and Baweanese. Singapore: Institute of Southeast Asian Studies (ISEAS).

Poliaus, I. 2014. The past in the present: A living heritage approach-Meteora, Greece. London: Ubiquity Press.

Rahimah Abdul Aziz, Halimaton Saadiah Hashim, Ong Puay Liu, Geraldine Chan Kim Ling, Sarah Aziz, Ruslin Amir and Sharina Abdul Halim. 2015. Laporan penglibatan pihak berkepentingan dalam governans pemuliharaan warisan: Bandaraya Melaka Bersejarah. Laporan akhir penyelidikan. Bangi: The Institute for Environment and Development (LESTARI), UKM.

Singh, S. R., Mohammad Reza Eghdami and S. Singh. 2014. The concept of social vulnerability: A review from disasters perspectives. International Journal of Interdisciplinary and Multidisciplinary Studies (IJIMS) 1(6): 71-82. https:// pdfs.semanticscholar.org/f6bd/4afdfab5f57d0fbc1d62675b03cf3abdc5e7.pdf (accessed 20 December 2016). 
Siti Norlizaiha Harun and Izzamir Ismail. 2011. The conservation plan for World Heritage Site: George Town, Penang and Malacca, Malaysia. The 1st International conference on rebuilding place: From culture to art and architecture, University Kuala Syiah, Banda Acheh, Indonesia. 4 October. https://www.academia. edu/6035394/THE_CONSERVATION_PLAN_FOR_WORLD_HERITAGE_ SITE_GEORGE_TOWN_PENANG_ANDD_MALACACA_MALAYYSIA

Sr Brit Anak Kayan. 2015. University-community engagement programme: A case study of traditional Melakan house inspection in Malacca Historical City, Malaysia. The Australasian Journal of University-Community Engagement 10(1): 1-40.

Starproperty.my. 2013. Malacca's most famous Malay village, Kampung Morten, is named after a british-era collector of land revenue. 11 October. http://www. starproperty.my/index.php/articles/property-news/malaccas-most-famous-malayvillage-kampung-morten-is-named-after-a-british-era-collector-of-land-revenue/ (accessed 12 December 2016).

Stovel, H. 2004. Authenticity in conservation decision-making: The world heritage perspective. Journal of Research in Architecture and Planning, Conservation and Cultural Heritage Volume 3: 1-8.

1998. Risk preparedness: A management manual for World Cultural Heritage. Rome: ICCROM. http://www.iccrom.org/ifrcdn/pdf/ICCROM_17_ RiskPreparedness_en.pdf (accessed 20 December 2016).

United Nations Development Programme (UNDP). 2004. Reducing disaster risk: A challenge for development. A global report. New York: UNDP-Bureau for Crisis Prevention and Recovery (BRCP).

United Nations Educational, Scientific and Cultural Organization (UNESCO). 2010. Community-based approach to museum development in Asia and the Pacific for culture and sustainable development. Paris: UNESCO.

1972. UNESCO Convention concerning the protection of world cultural and natural heritage. http://whc/unesco.org/en.conventiontext/ (accessed 20 December 2016).

Varutti, M. 2010. The politics of imagining and forgetting in Chinese ethnic minority museums. Outlines - Critical Practice Studies 12(2): 69-82.

World Heritage Centre (WHC). 2008. Operational guidelines for the implementation of the world heritage convention. Paris: UNESCO, World Heritage Centre. http://whc. unesco.org/archive/opguide08-en.pdf (accessed on 14 July 2017).

2005. Operational guidelines for the implementation of the world heritage convention. Paris: UNESCO World Heritage Centre.

Wijesuriya, G. 2005. The past is in the present: Perspectives in caring for Buddhist heritage sites in Sri Lanka. In Conservation of living religious heritage: Papers from the ICCROM 2003 Forum on living religious heritage, conserving the sacred, eds. $\mathrm{H}$. Stovel, N. Stanley-Priceand R. Killick. Rome, Italy: International Centre for the Study of the Preservation and Restoration of Cultural Property (ICCROM).

Xie, P. F. 2004. Visitors' perception of authenticity at a rural heritage festival: A case study. Event Management 8: 151-160. https://doi.org/10.3727/1525995031436908. 